Agro-Science Journal of Tropical Agriculture, Food, Environment and Extension Volume 8 Number 2 May 2009 pp $90-96$

ISSN 1119-7455

\title{
MEASUREMENT OF TECHNICAL EFFICIENCY AND ITS DETERMINANTS IN CROP PRODUCTION IN LAFIA LOCAL GOVERNMENT AREA OF NASARAWA STATE, NIGERIA
}

\author{
Rahman, S.A. and Umar H.S. \\ Department of Agricultural Economics and Extension Nasarawa State University, Keffi, Lafia \\ Campus, Lafia, Nigeria.
}

\begin{abstract}
This study was designed to measure technical efficiency and identify its determinants in crop production in Lafia Local government Area of Nasarawa State of Nigeria using a stochastic frontier production model. Double stage random sampling technique was used to select 100 crop farmers from which input-output data were collected based on 2005 cropping season. The results revealed that sixty five percent (65\%) of the farmers were within the age range of 31-50 years and $67 \%$ had farm size ranging from 2-4 hectares. The technical efficiency of crop production range from $32.7 \%$ to $89.4 \%$ with mean of $69.6 \%$. Farm size and fertilizer were the major inputs that are associated with the variation in crop output. The significant socio economic variables that accounted for the observed variations in technical efficiency among crop farmers were age, gender, marital status, household size, other occupation and land ownership. It is therefore recommended that a land redistribution policy that will increase the farm size of the farmers should be initiated. Fertilizer supply at subsidized rate to farmers in the area should be encouraged.
\end{abstract}

Key words: Technical Efficiency, Determinants, Crop Production.

\section{INTRODUCTION}

Efficiency measurements have been attempted in several studies (Shanmugan and Palanisami, 1993; Jayaram et al., 1989; Hang and Bagi, 1984; Kalirajan, 1981 and Junakar, 1980). There are two approaches to efficiency measurement; these are parametric stochastic frontier production function and the non parametric mathematical programming, commonly referred to as Data Envelopment Analysis (Sharma et al 1999, Charnes et al., 1978, Aigner et al., 1977 and Meeusen and Broeck, 1977).

In the stochastic frontier production function approach, an efficient farm is said to operate on the production frontier while inefficient farms are those operating below the production frontier. A technically efficient farm produces the maximum possible output from inputs used, given locational and environmental constraints and it minimizes resources used for any given level of output (Rahman et al., 2005). Several factors including socio-economic and demographic factors, farm plot level characteristics, environmental factor and non-physical factors are likely to affect the efficiency of small holding farmers. Parikh et al (1995), used stochastic cost frontier to analyze Pakistani agriculture in a two-stage estimation procedure. They found that education, number of working animals, credit per acre and number of extension visits significantly increased cost efficiency while large land holding size significantly decreased cost efficiency.

In single estimation approach of the technical efficiency model for Indian farmers, Colli et al (1998), found that years of schooling, land size and age of farmers are positively related to technical efficiency. Seyoum et al (1998) investigated the technical efficiency of maize produce in Ethiopia and compare the performance of farmers within and outside the programme of technology demonstration, using Cobb-Douglas stochastic production functions. Their empirical results showed that farmers that participated in the programme are more technically efficient with mean technical efficiency equal to $94 \%$ compared to $79 \%$ for those outside the project. Thus, most of the empirical studies show that 
socio-economic characteristics and farm characteristics are important sources of technical efficiency among farmers.

This study, therefore, is an attempt aimed at measuring technical efficiency and

(i) describe socio-economic characteristics of the crop farmers;

(ii) estimate input-output relationship in crop production;

(iii) determine technical efficiency in crop production and,

(iv) identify socio-economic factors influencing technical efficiency in crop production.

\section{MATERIALS AND METHODS}

This study was conducted in Lafia Local Government Area of Nasarawa State. The area which is located in South Geopolitical zone of Nasarawa State lies between latitude $08^{0} 33^{1} \mathrm{~N}$, and longitude $08^{0} 32^{1} \mathrm{E}$ and altitude $181.53 \mathrm{~m}$ (Meteorological department, Lafia Nasarawa State, 2005). The average annual rainfall is approximately $1,288 \mathrm{~mm}$ and annual mean temperature range from $22.7^{\circ}$ $36.8^{\circ}$. The soil texture is predominantly sandy-loam. Sorghum, cowpea, rice, maize, sesame, groundnut and cassava are the main crops grown in the area. The Local Government Area has a population of 330,712 people, made up of 169,398 males and 161,314 females (NPC, 2006). A two stage random sampling technique was adopted for this study. In each of the five districts in the study area, two villages were randomly selected. In each of the ten villages selected, ten farmers were randomly sampled, giving rise to a total of one hundred (100) farmers which were used for the study.

Primary data were collected using structured questionnaire. The data were collected for 2005 cropping season. Information collected include labour input, capital inputs, output, prices and farmers' socio-economic characteristics such as age, farming experience, level of education, household size and land ownership. The analysis of data was done by estimation of stochastic frontier production function model.

\section{The Model Specification}

The stochastic frontier function used by Onu et al (2000) and Parikh and Shah (1995) as derived from the error model of Aigner, Lovell and Schmidt (1977) were applied for this study. The stochastic identifying factors determining its magnitude in general crop production in Lafia Local Government Area of Nasarawa State, Nigeria. The specific objectives for this study include to:

production with a multiplicative disturbance term of the farm is shown below:

$\mathrm{Y}=\mathrm{F}(\mathrm{X} \beta) \exp ^{\mathrm{E}}$....

$\mathrm{Y}=$ The value of

farm outputs

$\mathrm{X}=$ Vector of input quantities

$\beta=\mathrm{a}$ vector parameters

$\mathrm{E}=$ Stochastic disturbance term consisting of two independent elements $\mathrm{U}$ and $\mathrm{V}$.

\section{Where}

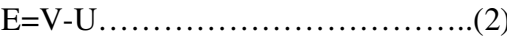

The symmetric component, V, accounts for factors outside the farmers' control, such as weather and diseases. It is assumed to be independent and identically distributed normal random variable $\left(\mathrm{O}, \delta \mathrm{V}^{2}\right)$. A one side component $\mathrm{U} \leq \mathrm{O}$ reflects the technical inefficiency relative to the stochastic frontier, $\mathrm{F}(\mathrm{X} \beta) \mathrm{E}$. The distribution of $\mathrm{U}$ is half normal. The stochastic production frontier model can be used to analyze cross sectional data. The model simultaneously estimates the individual efficiency of the respondent farmers as well as determinants of technical efficiency (Batesse and Coelli, 1995). The frontier of the farm is given by combining (1) and (2).

$\mathrm{Y}=\mathrm{F}(\mathrm{X} \beta) \exp ^{(\mathrm{V}-\mathrm{U})}$

Measures of efficiency for each farm can be calculated as

$\mathrm{TE}=\frac{\mathrm{F}(\mathrm{X} \beta) \exp ^{(\mathrm{V}-\mathrm{U})}}{\mathrm{F}(\mathrm{X} \beta)}=\exp ^{(\mathrm{v}-\mathrm{u})}$

The empirical stochastic frontier production model that was used is specified as follows:

In $Y_{1}=\beta_{0}+\beta_{1}$ In $X_{1 i}+\beta_{2}$ In $X_{2 i}+\beta_{3}$ In $X_{3 i}+\beta_{4}$

In $X_{4 i}+\beta_{5}$ In $X_{5 i}+V_{i}-U_{i}$

Where subscripts ij refers to the jth observation of ith farmer

$\mathrm{In}=$ Logarithm to base e,

$\mathrm{Y}=$ value of crops output in aggregate ( $)$

$\mathrm{X}_{1}=$ Farm size (hectares)

$\mathrm{X}_{2}=$ Labour used in crop production (man hours)

$\mathrm{X}_{3}=$ Seeds cost $(\AA)$

$\mathrm{X}_{4}=$ Chemical costs $(\#)$

$\mathrm{X}_{5}=$ Fertilizer $(\mathrm{kg})$

It is assumed that inefficiency effects are independently distributed and Uij arises by truncation (at zero) of the normal distribution with mean $\mathrm{Uij}$ and variance $\delta \mathrm{U}^{2}$ where $\mathrm{Uij}$ 
Specified as; $\mathrm{U}_{\mathrm{i}}=\delta_{0}+\delta_{1}$ In $\mathrm{Z}_{1 \mathrm{i}}+\delta_{2}$ In $\mathrm{Z}_{2 \mathrm{i}}+\delta_{3}$ In

$\mathrm{Z}_{3 \mathrm{i}} \ldots$

\section{Where}

$\mathrm{U}_{\mathrm{i}}=$ technical inefficiency of the ith farmer

$\mathrm{Z}_{\mathrm{i}}=$ Farmer's age (yrs)

$\mathrm{Z}_{2}=$ Years of farming experience of the ith farmer in crop production

$\mathrm{Z}_{3}=$ Amount of credit obtained by the ith farmer (

$\mathrm{Z}_{4}=$ Annual income level ( $)$

$\mathrm{Z}_{5}=$ Years of formal education of the ith farmer $\mathrm{Z}_{6}=$ Gender of the ith farmer measured as dummy (if male 1,0 otherwise)

$\mathrm{Z}_{7}=$ Marital Status of the ith measured as dummy (if married 1, 0 otherwise)

$\mathrm{Z}_{8}=$ Household size of ith farmer (number of people)

$Z_{9}=$ Major occupation of the ith farmer measured as dummy (if major is farming 1, 0 otherwise)

$\mathrm{Z}_{10}=$ Other occupation of the ith farmer measured as dummy (if engaged in any other occupation 1, 0 otherwise)

$\mathrm{Z}_{11}=$ Land ownership status of the ith farmer measured as dummy (if own 1, 0 otherwise) $\mathrm{Z}_{12}=$ Number of crops grown by ith farmer

\section{RESULTS AND DISCUSSION}

The socio-economic characteristics of the respondents are presented in Table 1 . The study revealed that majority of household heads $(94 \%)$ were males. The age of the farmers ranged between 21 and 60 years. Majority of the respondents $(65 \%)$ were between the age of 31 and 50 years. The mean age was 44.3 years. This implies that majority of the farmers were youth; an economic active age that can make positive contribution to agricultural production. Most respondents $(80 \%)$ are married. This contributed widely to the use of family labour by the households as the wives and children constituted the labour force. The literacy level among the farmers in the study area was high. Njoku (1991) observed that formal education has a positive influence on adoption of innovation. In the study area, $49 \%$ of respondents had secondary education. Majority of the respondents (62\%) had more than 11 years of farming experience, and this shows that the managerial ability of the farmers can be inferred to be reasonably good. The study also revealed that a large proportion of the respondents $(67 \%)$ had farm size of 2-4 hectares which were mostly $(70 \%)$ acquired through inheritance. The larger the arm size, the higher the tendency of diversification of crop production thus leading to production for home consumption and for sale (Minot, 1999). The household size of most respondents (88\%) ranged between 1 and 10 members. A large household size also means more mouth to feed, such that for a given farm size large households could produce a smaller market surplus (Minot et al, 2006). However, in traditional agriculture, the larger the household size the more labour force is available for farm activities.

The maximum likelihood Estimates (MLE) of the stochastic production parameters for the crops (in aggregate) are presented in Table 2. The coefficient of farm size and fertilizer are statistically significant. The variance of the farm effect is found to be significant proportion of the total variability of the value of crops production (in aggregate). Gamma $(\gamma)$ is estimated as 0.778 which implies that $77.8 \%$ of the total variation in aggregate crops output is due to technical inefficiency. The parameter Lambda $(\lambda)$ is greater than one. Such a result according to Tadesse and Krishnamoorthy (1997), indicates a good fit for the model. The coefficient of farm size $\left(\mathrm{X}_{1}\right)$ and fertilizer $\left(\mathrm{X}_{5}\right)$ were 0.387 and 0.786 and both were statistically significant. These coefficients denotes the variation or possible change in aggregate output of crops as a result of a unit change in the input

The frequency distributions of efficiency estimates obtained from the stochastic frontier model (Table 3) shows that the $27 \%$ of the farmer operated below efficiency level of $60 \%$. The mean technical efficiency for sample is $69.6 \%$ with minimum of $32.7 \%$. This implies that on the average, farmers were able to obtained $69.6 \%$ potential output from a given combination of production inputs. The implication of the result is such that the average crop farmers requires $34 \%$ i.e. $\{(1-0.696 / 0.894)\} 100$ cost saving to attain the status of the most efficient crop farmer while least performing farmers would need $76 \%$ i.e. $\{(1-0.327 / 0.894)\} 100$ cost saving to become the most efficient farmer. 
Table 1 Socio Economic Characteristics of the Farmers in the Study Area

\begin{tabular}{|c|c|c|}
\hline Characteristics & Frequency & Percentage \\
\hline \multicolumn{3}{|l|}{ Gender } \\
\hline Male & 94 & 94 \\
\hline Female & 6 & 6 \\
\hline Total & 100 & 100 \\
\hline \multicolumn{3}{|l|}{ Ages in years } \\
\hline 21-30 & 11 & 11 \\
\hline $31-40$ & 32 & 32 \\
\hline $41-50$ & 33 & 33 \\
\hline $51-60$ & 20 & 20 \\
\hline Above 60 & 4 & 4 \\
\hline Total & 100 & 100 \\
\hline \multicolumn{3}{|l|}{ Marital Status } \\
\hline Married & 80 & 80 \\
\hline Single & 6 & 6 \\
\hline Divorce & 7 & 7 \\
\hline W idowed & 7 & 7 \\
\hline Total & 100 & 100 \\
\hline \multicolumn{3}{|l|}{ Level of Education } \\
\hline Primary school & 15 & 15 \\
\hline Secondary school & 49 & 49 \\
\hline Tertiary education & 18 & 18 \\
\hline Adult education & $\mathbf{0}$ & $\mathbf{0}$ \\
\hline Quranic education & 4 & 4 \\
\hline No formal education & 14 & 14 \\
\hline Total & 100 & 100 \\
\hline \multicolumn{3}{|l|}{ Household size } \\
\hline $1-5$ & 40 & 40 \\
\hline $6-10$ & 48 & 48 \\
\hline 11-15 & 7 & 7 \\
\hline $16-20$ & 2 & 2 \\
\hline Above 20 & 3 & 3 \\
\hline Total & 100 & 100 \\
\hline \multicolumn{3}{|c|}{ Years of farming experience } \\
\hline $1-10$ & 38 & 38 \\
\hline $11-20$ & 44 & 44 \\
\hline $21-30$ & 14 & 14 \\
\hline 31 and above & 4 & 4 \\
\hline Total & 100 & 100 \\
\hline \multicolumn{3}{|l|}{ Farm size (ha) } \\
\hline$<2$ & 26 & 26 \\
\hline $2-4$ & 67 & 67 \\
\hline $4-6$ & 7 & 7 \\
\hline Total & 100 & 100 \\
\hline \multicolumn{3}{|l|}{ Landownership } \\
\hline Owned land & 70 & 70 \\
\hline Lease land & 30 & 30 \\
\hline Total & 100 & 100 \\
\hline
\end{tabular}

Source: Field survey, 2005: 
The determinants of technical efficiency in crops production in the study Area (Table 4) indicates that farmer's age was positive and significantly related to technical efficiency. The mean age was 44 years. This result however disagree with those of Onyeweaku et al (2004) whose result showed age to be positive and not significant with technical efficiency. Farming experience is negative and not significantly related to technical efficiency. This result disagrees with that of Onyeweaku and Nwaru (2005). Education shows no significant relationship with technical efficiency. This agrees with that of Onyeweaku and Effiong (2005), but disagrees with Onu, et al (2000). Gender is positive and significantly related to technical efficiency. This result tally with that of Ohajianya (2005). The marital status is positive and significantly related to technical efficiency. Amount of credit obtained was positive and showed no significant relationship with technical efficiency. Annual income was positive and show no significant relationship with technical efficiency. Household size was negative and significantly related to technical efficiency. This result disagrees with that of
Onyenweaku and Effiong (2005), but is in consonance with Onyenweaku and Nwaru (2005). Major occupation was negative and not significantly related to technical efficiency. Other occupation was negative and significantly related to technical efficiency. Land ownership was positive and significantly related to technical efficiency. Finally, number of crop grown was positive and not significantly related to technical efficiency. Thus, age, gender, marital status, household size, other occupation and land ownership have significant relationship with efficiency. While farming experience, amount of credit obtained, annual income, educational status, major occupation and number of crops grown are not significantly related to technical efficiency

Table 2 Maximum Likelihood Estimates of the parameter of the Stochastic Frontier Production Function

\begin{tabular}{lllll}
\hline Variable & Parameters & Coefficient & Standard error & T-ratio \\
\hline Constant & $\beta_{0}$ & 0.479 & 0.836 & 0.573 \\
Farm size $\left(\mathrm{X}_{1}\right)$ & $\beta_{1}$ & 0.387 & 0.208 & $1.861^{* *}$ \\
Labour $\left(\mathrm{X}_{2}\right)$ & $\beta_{2}$ & 0.116 & 0.542 & 0.214 \\
Seed $\left(\mathrm{X}_{3}\right)$ & $\beta_{3}$ & 0.278 & 0.228 & 1.219 \\
Chemical $\left(\mathrm{X}_{4}\right)$ & $\beta_{4}$ & 0.277 & 0.430 & 0.644 \\
Fertilizer $\left(\mathrm{X}_{5}\right)$ & $\beta_{5}$ & 0.786 & 0.135 & $5.822^{* * *}$ \\
Sigma-Squared & $\delta^{2}$ & 0.323 & 0.214 & 1.509 \\
Gamma & $\Gamma$ & 0.778 & 0.262 & 2.969 \\
Lambda & $\Lambda$ & 3.504 & & \\
Log likelihood & -0.497 & & & \\
\hline
\end{tabular}

Source: Data Analysis, 2005.

Note:*** Significant at $1 \% * *$ significant at $5 \%$

\section{Table 3. Frequency Distribution of Technical Efficiency Indices}

\begin{tabular}{lll}
\hline Technical Efficiency Range & Frequency & Percentage \\
\hline$\leq 0.40$ & 2 & 2 \\
$0.41-0.60$ & 25 & 25 \\
$0.61-0.80$ & 45 & 45 \\
$0.81-1.00$ & 28 & 28 \\
Total & 100 & 100 \\
\hline
\end{tabular}


Table 4: Determinant of Technical Efficiency in Crop Production

\begin{tabular}{lllll}
\hline Variable & Parameter & Coefficient & Stand error & T-ration \\
\hline Constant & $\mathrm{q}_{0}$ & 57.431 & 3.712 & $15.472^{* *}$ \\
Age $\left(\mathrm{Z}_{1}\right)$ & $\mathrm{q}_{1}$ & 4.479 & 1.645 & $2.723^{* *}$ \\
Farming experience $\left(\mathrm{Z}_{2}\right)$ & $\mathrm{q}_{2}$ & -0.861 & 0.471 & -1.828 \\
Amount of credit obtained $\left(\mathrm{Z}_{3}\right)$ & $\mathrm{q}_{3}$ & 1.010 & 0.611 & 1.653 \\
Annual Income $\left(\mathrm{Z}_{4}\right)$ & $\mathrm{q}_{4}$ & 2.253 & 1.021 & 2.207 \\
Educational status $\left(\mathrm{Z}_{5}\right)$ & $\mathrm{q}_{5}$ & -1.344 & 0.411 & -3.270 \\
Gender $\left(\mathrm{Z}_{6}\right)$ & $\mathrm{q}_{6}$ & 2.352 & 0.466 & $5.047^{* *}$ \\
Marital Status & $\mathrm{q}_{7}$ & 2.337 & 0.594 & $3.934^{* *}$ \\
Household size $\left(\mathrm{Z}_{8}\right)$ & $\mathrm{q}_{8}$ & -2.100 & 0.998 & $-2.104^{* *}$ \\
Major Occupation & $\mathrm{q}_{9}$ & -0.173 & 0.059 & -2.932 \\
Other occupation $\left(\mathrm{Z}_{9}\right)$ & $\mathrm{q}_{10}$ & -10.784 & 1.806 & $3.971^{* *}$ \\
Land ownership $\left(\mathrm{Z}_{11}\right)$ & $\mathrm{q}_{11}$ & 2.704 & 0.796 & $0.877^{* *}$ \\
Number of Crop Grown $\left(\mathrm{Z}_{12}\right)$ & $\mathrm{q}_{12}$ & 1.128 & 1.293 & \\
\hline
\end{tabular}

$* *=5 \%$ significant

NS=Not significant

\section{CONCLUSION}

The results of the study revealed that technical efficiency in crop production in Lafia Local Government Area of Nasarawa State range from $32.7 \%$ to $89.4 \%$ with a mean of $69.6 \%$. This means that there are substantial opportunities to increase productivity and income through more efficient utilization of productive resources. Important factors related to technical efficiency were labour, fertilizer, age, gender, household size, marital status, other occupation and land ownership.

\section{RECOMMENDATION}

The study revealed that farm size and fertilizer are positive significant factors influencing crop production in the Local Government Area. A land redistribution policy that will increase the farm size of farmers since they are mainly small scale farmers will boost crop production. Timely and adequate supply of fertilizer at subsidized rate will enhance the output of crops on farms.

\section{REFERENCES}

Aigner, D. J: Lovell, C.A.K and Schmidt P. (1977). Formulation and estmation of stochastic production function model Journal of Econometrics 6:21-37.

Betesse G. E. and Colli, T. (1995). A model of Technical Inefficiency Effects in a stochastic Friontier Production function for Panel Data. Empirical Economics 20:325-332

Charnes A; Cooper W. W. and Rhodes. E. (1978). Measuring the efficiency of decision making units. European Journal of Operation Research 2429444.
Coelli T; Rao, D.S. and Batese G.E. (1998). An Introduction to efficiency and productivity Analysis Kluver Academic Publishers, Norwell, M. C.

Hang, C.J. and Bagi, F.S. (1984). Technical Efficiency on individual farmers on North West India: Southern Econimic Journal 15(1): 108-115.

Jayaram H.G.S. Chandrashekar L. and Achoth L. (1987). An Economic analysis of technical efficiency in rive cultivation in Mandhya: some Issues in resource priving" Indian Journal of Agricultural Economics 47:657-667.

Junakar, P.N. (1980). Test of the profit maximization hypothesis: A study of Indian Agriculture Journal of Development Studies 16:87-203

Kaliranjan K. (1981). An Economic Analysis of yield variability in Paddy production Canadian Journal of Agricultural Economics 29:283-294

Meusen, N. and Van Den Broeck, J. (1977). Efficiency estimation from Cobb Douglas production function with composite error International Economics Reviews.18(2) 123-134.

Minot, N. Epprecht M, Anh T.T.T. and Trung L.Q (2006). Income diversification in the Northern upland of Vietnarn research 145. International Food Policy Research Institute Washington D.C.

Minot, N. (1999). Effect of transition cost in supply response and market surplus: Simulation using non-separable household model: Discussion paper No 36 Market structure study Division. International Food Policy Research Institute Washington D.C. 
Rahman, S.A. and Umar H.S.

NPC (2006). National Population Commission: Details of the Breakdown of Nasarawa State Provisional 2006 Local Government Census result.

Njoku, J.E. (1991). Factors Influencing the adoption of improve oil palm production technologies by small holders in Imo state, Nigeria In: Olukosi J.O. Ogungbile A.O. and Kalu B.A. (eds) Appropriate Agricultural Technologies for Resource poor framer. A publication of the Nigerian Farming System Research Network p. 25

Okike, I. (2000). Crop/Livestock Interactions and Economic Efficiency of Farmer in the Savannah Zone of Nigeria, Ph.D. Thesis, Department of Agricultural Economics, University of Ibadan 155 pp.

Onu, J.K Amaza P.S and Okunmadewa F.Y. (2000). Determinant of Cotton Production and Economic Efficiency. African Journal of Business and Economic Research 1(2): 24:30.

Onyeweaku, C.E. and Effiong E.O. (2005). Technical Efficiency in pig production in Akwa Ibom State Nigeria International Journal of Agriculture and Rural Development 6:51-58.

Onyeweaku, C.E. and J.C. Nwaru (2005). Application of stochastic frontier production function to the measurement of technical efficiency in food crop production in Imo State, Nigeria The Nigerian Agriculture Journal 36:1-12

Ohajianya D.O. (2005) Economics efficiency among small scale poultry in Imo state; Stochastic Frontier Production Model Approach. International Journal of Agriculture and Rural Developmentl. 6:18:25.
Onyenweaku, C.E. Igwe K.C. and Mbanor J.A. (2004). Application of stochastic frontier production function to the measurement of technical efficiency in yam production on Nasarawa State, Nigeria. Journal of Sustainable Tropical Agricultural Research 13:2025

Parikh, A.F. Ali and M.K. Shah (1995). "Measurement of Economic Efficiency in Pakistani Agriculture" American Journal of Agricultural Economics 77:657-685.

Rahman S.A. Ajayi F.A. and Gabriel J. (2005). "Technical efficiency in Sorghum based cropping systems in Soba Area of Kaduna State Nigeria Journal of Research in Science and Management 3(1): 100-104.

Seyoum E.I. Bathese G.E. and Flemmeng E.M. (1998). Technical efficiency and productivity of Maize production in Eastern Ethiopia Journal of Agricultural Economics 1: 341-348

Shanmugan T.R. and Palanisami K. (1993). Measurement of economic efficiency: Frontier function approach Journal of Indian Society of Agricultural statistics. 45:235-242.

Sharma, K.R. Leung P. and Zaleski H.M. (1999) Technical Allocative and Economic Efficiency in Swine production in Hawaii: A comparison of parametric and non-parametric approaches Journal of Agricultural Economics 20-35

Tadesse, B. and Krishnamoorthy S. (1997) Technical Efficiency of paddy farmers of Tamil Nadu: and analysis based on farm and ecological zone Journal of Agricultural Economics 16:185-192. 